Research Article

\title{
Health Risk Assessment of Heavy Metals in Soils before Rice Sowing and at Harvesting in Southern Jiangsu Province, China
}

\author{
Chenghui Han $\mathbb{D}^{1},{ }^{1}$ Weifang Xie, ${ }^{1}$ Chen Chen, ${ }^{2}$ and Ting Cheng ${ }^{1}$ \\ ${ }^{1}$ School of Environment and Ecology, Jiangsu Open University, Nanjing 210036, China \\ ${ }^{2}$ School of Environmental and Chemical Engineering, Jiangsu University of Science and Technology, Zhenjiang 212003, China \\ Correspondence should be addressed to Chenghui Han; 15185785754@sina.cn
}

Received 6 June 2020; Revised 3 August 2020; Accepted 18 September 2020; Published 30 September 2020

Academic Editor: Woojin Lee

Copyright $(02020$ Chenghui Han et al. This is an open access article distributed under the Creative Commons Attribution License, which permits unrestricted use, distribution, and reproduction in any medium, provided the original work is properly cited.

Rice, one of the most important staple crops in China, is easily contaminated by heavy metal pollution from industrial development. In this work, we systematically investigated the heavy metal $(\mathrm{Cr}, \mathrm{Cd}, \mathrm{Pb}, \mathrm{Zn}$, and $\mathrm{Cu})$ and metalloid $(\mathrm{Hg}$ and $\mathrm{As})$ concentrations in paddy soils and different rice tissues in southern Jiangsu Province, China. The potential ecological hazard index method and in vitro simulation test were used to evaluate the influence of heavy metals on local resident health. The results showed that, before rice sowing and at the harvesting period, the order of $E_{r}^{i}$ values was $E_{r}^{i}(\mathrm{Cd})>E_{r}^{i}(\mathrm{Hg})>E_{r}^{i}(\mathrm{As})>E_{r}^{i}(\mathrm{~Pb})>E_{r}^{i}(\mathrm{Cu})>E_{r}^{i}(\mathrm{Cr})>E_{r}^{i}(\mathrm{Zn})$. The low-risk index values (91.63 and 30.29) for the heavy metals indicated the low risk at the two stages in the study area based on the potential ecological hazard index. As determined with Tessier's five-stage sequential extraction procedure, the proportions of the chemical speciation of the heavy metals were as follows: residual > organic matter-bound $>$ iron-manganese oxide-bound $>$ carbonate-bound $>$ exchangeable. The order of the values of the accumulation and transfer factors was $\mathrm{Cd}(3.16)>\mathrm{Cu}(0.42)>\mathrm{Zn}(0.28)$ $>\mathrm{Pb}(0.25)>\mathrm{As}(0.07)>\mathrm{Cr}(0.04)>\mathrm{Cr}(0.03)$ and root $>$ stem $>$ leaves, respectively. In vitro simulation tests showed that, in both adults and children, the daily amount of $\mathrm{Pb}$ and $\mathrm{Cd}$ intake through the soil-oral cavity route in the study area did not exceed the daily tolerance for $\mathrm{Pb}$ and $\mathrm{Cd}$ proposed by the WHO. In summary, although there is no obvious danger to local adults and children, it is necessary to be aware of the possibility of rice contamination from $\mathrm{Cd}$ in the soil.

\section{Introduction}

Heavy metal pollution has been widely studied due to the toxicity of heavy metals to plants and humans $[1,2]$. Heavy metals irreversibly change the structure of proteins, which can affect the functions of tissues and cells [3]. Heavy metals harm human health when excessive levels of heavy metals accumulate in animals and plants through the food chain due to their inability to biodegrade in the environment [4]. Heavy metal pollution in soil mainly comes from industrial activities, traffic, and domestic waste pollution [5]. However, unpolluted soil is essential for ensuring the safety of edible crops. Therefore, the degree of heavy metal pollution in soils must be effectively evaluated.

Rice, as one of the most important staple crops in China, is of great significance for ensuring the sustainable and stable development of agriculture in China $[6,7]$. Excessive concentrations of heavy metals in rice directly endanger the health of those who consume the rice. In addition to industrial pollution (mining, smelting, pesticides, and automobile exhausts), fertilization is the main factor causing heavy metal pollution in farmland [8]. In particular, Cd is relatively more toxic to humans than other heavy metals [9]. Unfortunately, $\mathrm{Cd}$ accumulates in rice more easily than other heavy metals, such as $\mathrm{Hg}, \mathrm{As}, \mathrm{Pb}, \mathrm{Zn}, \mathrm{Cu}$, and $\mathrm{Cr}$. Wang et al. [10] performed a risk assessment of Cd-polluted paddy soils in industrial and township areas in Hunan, South China. The results showed that the Cd contents of paddy soils averaged $0.228-1.91 \mathrm{mg} / \mathrm{kg}$, and $90 \%$ of the soil samples exceeded the allowable limit of $0.3 \mathrm{mg} / \mathrm{kg}$ stipulated by the China Soil Environmental Quality Standards. More than seventy percent (39 of 53) of the grain samples exceeded the limited concentration of Cd. Liu et al. [11] explored the spatial patterns of $\mathrm{Cd}$ in paddy soils in China, performed a 
preliminary evaluation of the potential risks, and identified the most critically contaminated regions based on the domestic rough rice trade flows. The results showed that $\mathrm{Cd}$ concentrations in paddy soils in China ranged from 0.01 to $5.50 \mathrm{mg} / \mathrm{kg}$, with a median value of $0.23 \mathrm{mg} / \mathrm{kg}$. On average, the highest $\mathrm{Cd}$ concentrations were found in Hunan $(0.73 \mathrm{mg} / \mathrm{kg})$, Guangxi $(0.70 \mathrm{mg} / \mathrm{kg})$, and Sichuan $(0.46 \mathrm{mg} /$ $\mathrm{kg}$ ) Provinces. The Cd concentrations in paddy soils in the central and western regions were higher than those in the eastern regions and much higher than those in the southeastern coastal regions. Zhang et al. [12] described the speciation and accumulation pattern of heavy metals from soil to rice at different growth stages in farmland in southwestern China. Considering the total amount and chemical forms of $\mathrm{Cd}$, they suggested that it was necessary to notify the appropriate departments about the possibility of rice contamination from $\mathrm{Cd}$ in the soil. Generally, it was found that many areas in China have been polluted by heavy metals, especially the areas surrounding industrial plants and mining areas. Hence, it is urgent to objectively evaluate the degree of heavy metal pollution in soils and the relevance of heavy metals in farmland to soil and rice safety.

Nanjing city, one of the most important economic development cities in southern Jiangsu Province, China, has made great contributions to national economic growth. However, environmental issues have gradually emerged with this rapid economic development. Wang et al. [13] explored the main influencing factors for human health risks from heavy metals along the Yangtze River in Nanjing, southeastern China. Cd represented the highest potential ecological risk in soils and sediments, as it possessed high bioaccessibility and bioaccumulation factors. A total of $5.97 \%$ of the target hazard quotient (THQ) values for $\mathrm{Cd}$ were higher than 1, indicating a potential health risk from plant consumption. Pollution from the upper reaches of the river and from agricultural activities had a greater impact on health risks than pollution from industrial activities in the study area. Shen et al. [14] measured the concentrations of heavy metals (As, $\mathrm{Cr}, \mathrm{Cd}, \mathrm{Cu}, \mathrm{Zn}, \mathrm{Mn}, \mathrm{Ni}$, and $\mathrm{Pb}$ ) in the water, sediment, and three common plants (Rorippa indica, Rumex acetosa, and Orychophragmus violaceus) from the Nanjing Forestry University reach of the Zihu River, China. The results showed that the toxicity threshold values exceeded the upper limits for $\mathrm{Cd}$ and $\mathrm{Mn}$ in the water. In the same way, the toxicity threshold values exceeded the limits for $\mathrm{As}, \mathrm{Cd}, \mathrm{Cu}, \mathrm{Ni}, \mathrm{Pb}$, and $\mathrm{Zn}$ in sediment. Levels of $\mathrm{Cd}, \mathrm{Cu}$, $\mathrm{Mn}, \mathrm{Ni}, \mathrm{Pb}$, and $\mathrm{Zn}$ that exceeded recommended limits were also found in the rhizosphere soil. However, few reports have paid attention to heavy metals in soils and the surrounding plants, especially in the farmland around the Nanjing suburbs.

There are many evaluation methods for heavy metals in soils, e.g., the Nemerow pollution index [15], the geoaccumulation index [16], the potential ecological risk index [17], and health risk assessment [18]. The potential ecological risk index is based on the characteristics of heavy metals and their transport, transformation, and deposition in the environment. Heavy metals in soils or sediments are evaluated from the perspective of sedimentology $[19,20]$. In addition, the chemical speciation of heavy metals is an important index for exploring their biological toxicity and has been widely employed in investigating their effective absorption by plants [21]. In vitro tests have been used to simulate the incidental ingestion of soil by humans [22]. Overall, the objectives of this study were to (1) estimate the level of heavy metal pollution in paddy soils around a Nanjing suburb during different growth stages of rice using the potential ecological risk index; (2) determine the heavy metal concentrations in rice roots, leaves, and grains in the soil-rice system; and (3) investigate the effects of the incidental ingestion of soil by humans based on an in vitro simulation test.

\section{Materials and Methods}

2.1. Study Area. The study area is located in Xugao village, southwest of Hengxi street, Jiangning District, Nanjing city. The study area has a subtropical monsoon climate with abundant rainfall. The annual precipitation and average temperature are $1200 \mathrm{~mm}$ and $15.4^{\circ} \mathrm{C}$, respectively. The maximum annual temperature is $39.7^{\circ} \mathrm{C}$, the minimum is $-13.1^{\circ} \mathrm{C}$, and the annual average precipitation is $1106 \mathrm{~mm}$. Nanjing is rich in mineral resources and has the largest reserves of iron, copper, aluminum, zinc, gold, silver, strontium, and 15 other kinds of ores in Jiangsu Province. Rice and rape are the main agricultural products of Xugao village.

2.2. Sample Collection and Preparation. Lianjing 2, one of the main local rice cultivars, is a midmaturity midstem rice variety bred in 1992 by the systematic selection of single plants with moderate variations from rice in Taiwan. The total growth period of the variety is $154-155$ days. The rice variety has several features, e.g., height of $105 \mathrm{~cm}$, upright seedlings, narrow leaves, light green leaves, compact and straight plants, short leaf blades, and main stems with 5-6 nodes. Samples of the surface soil $(0-20-\mathrm{cm}$ depth) in the rhizosphere were collected before the sowing (May 2018) and harvesting stages (September 2018). Five sampling points were established in each sampling unit, avoiding ridges and roads as much as possible (Table 1).

\subsection{Heavy Metal Concentration Analysis. The properties and} heavy metal contents of the samples were measured according to the methods of the Green Food-Environmental Quality for Production Area (NY/T391-2013) of the People's Republic of China. The $\mathrm{pH}$ of the soils was determined in a $1: 2.5$ suspension in triplicate [23]. A pH meter with a platinum electrode was utilized to determine the redox potential (Eh) [24], whereas the potassium dichromate external heating method was used to measure the organic matter (OM) content in the soils [25]. Microwave digestion was employed to digest the soil samples and rice using $\mathrm{HNO}_{3}-\mathrm{HF}-\mathrm{H}_{2} \mathrm{O}_{2}(\mathrm{Cr}, \mathrm{Cd}, \mathrm{Pb}, \mathrm{Cu}$, and $\mathrm{Zn})$ and aqua regia ( $\mathrm{Hg}$ and $\mathrm{As}$ ), respectively $[26,27]$. $\mathrm{Hg}$ and As in rice were digested under high pressure and airtight conditions, and $\mathrm{HNO}_{3}-\mathrm{H}_{2} \mathrm{O}_{2}$ (3:1) was used for digestion. The chemical 
TABLE 1: Information of sampling points in this study area.

\begin{tabular}{|c|c|c|c|c|}
\hline Sampling coordinate & Sampling point number & Slope aspect $\left({ }^{\circ}\right)$ & Altitude (m) & Soil type \\
\hline $118^{\circ} 68^{\prime} 71.37^{\prime \prime} \mathrm{E}, 31^{\circ} 66^{\prime} 91.42^{\prime \prime} \mathrm{N}-118^{\circ} 8^{\prime} 67.78^{\prime \prime} \mathrm{E}, 31^{\circ} 66^{\prime} 92.06^{\prime \prime} \mathrm{N}$ & 5 & 9 & 35.25 & Calcareous soil \\
\hline $118^{\circ} 68^{\prime} 63.7^{\prime \prime} \mathrm{E}, 31^{\circ} 66^{\prime} 90.13^{\prime \prime} \mathrm{N}-118^{\circ} 68^{\prime} 69.12^{\prime \prime} \mathrm{E}, 31^{\circ} 66^{\prime} 87.83^{\prime \prime} \mathrm{N}$ & 5 & 12 & 34.79 & Calcareous soil \\
\hline $118^{\circ} 68^{\prime} 62.57^{\prime \prime} \mathrm{E}, 31^{\circ} 66^{\prime} 87.29^{\prime \prime} \mathrm{N}-118^{\circ} 68^{\prime} 68.58^{\prime \prime} \mathrm{E}, 31^{\circ} 66^{\prime} 84.76^{\prime \prime} \mathrm{N}$ & 5 & 8 & 35.05 & Calcareous soil \\
\hline $118^{\circ} 68^{\prime} 47.98^{\prime \prime} \mathrm{E}, 31^{\circ} 66^{\prime} 72.48^{\prime \prime} \mathrm{N}-118^{\circ} 68^{\prime} 50.77^{\prime \prime} \mathrm{E}, 31^{\circ} 66^{\prime} 71.09^{\prime \prime} \mathrm{N}$ & 5 & 7 & 34.47 & Calcareous soil \\
\hline $118^{\circ} 68^{\prime} 49.91^{\prime \prime} \mathrm{E}, 31^{\circ} 66^{\prime} 68.19^{\prime \prime} \mathrm{N}-118^{\circ} 68^{\prime} 44.33^{\prime \prime} \mathrm{E}, 31^{\circ} 66^{\prime} 68.51^{\prime \prime} \mathrm{N}$ & 5 & 10 & 34.36 & Calcareous soil \\
\hline
\end{tabular}

speciation of the heavy metals in the soils was determined using Tessier's five-stage sequential extraction procedure [28]. Then, the total contents of the heavy metals $(\mathrm{Cr}, \mathrm{Cd}, \mathrm{Pb}$, $\mathrm{Cu}$, and $\mathrm{Zn}$ ) in the aforementioned digested soil and rice samples were measured using inductively coupled plasma optical emission spectrometry. The concentrations of metalloids ( $\mathrm{Hg}$ and $\mathrm{As}$ ) in the soil and rice were determined using a nondispersive atomic fluorescence spectrometer (AFS-933, Beijing Jitian Instrument Co., Ltd.).

The vessels used were soaked in $25 \%-30 \% \mathrm{HNO}_{3}$ for longer than 8 hours and repeatedly washed with deionized water. Certified Standard Reference Materials (GSS-3) purchased from the State Bureau of Technical Supervision of China were used to ensure the accuracy and precision of the methods and results. The recovery rate of the heavy metals in the soil and rice samples ranged from $85.24 \%$ to $111.41 \%$.

\subsection{Risk Assessment Methods}

2.4.1. Risk Assessment Methods for Heavy Metals in Soils. The potential ecological hazard index method was proposed by Hakanson in 1980 [29]. This method was used to calculate the ecological hazard index, which includes the ratio of the content of a heavy metal in sediment to the highest background value of the same heavy metal in sediment before industrialization and the biological toxicity coefficient of the heavy metal [30]. The potential ecological risk factor for a given heavy metal $\left(E_{r}^{i}\right)$ is as follows:

$$
E_{r}^{i}=T_{r}^{i} \times \frac{C_{i}}{C_{0}}
$$

Equation (1) was used to calculate the risk index (RI) of the sampling sites as follows:

$$
\mathrm{RI}=\sum_{i=1}^{n} T_{r}^{i} \times \frac{C_{i}}{C_{0}},
$$

where $C_{\mathrm{i}}$ is the pollution factor for an individual heavy metal; $\mathrm{C}_{0}$ is the concentration of the same heavy metal in the background soil, which was obtained from the Soil Environmental Quality Risk Control Standard for Soil Contamination of Agricultural Land (GB15618-2018) in China (Table 2); $T_{r}^{i}$ is the biological toxicity factor of an individual element, which was defined as $\mathrm{Cd}=30, \mathrm{Cr}=2, \mathrm{Zn}=1$, $\mathrm{Hg}=40, \mathrm{As}=10$, and $\mathrm{Pb}=\mathrm{Cu}=5$ [30]; and $E_{r}^{i}$ is the potential ecological risk factor for a single heavy metal. RI is the comprehensive potential ecological hazard index, which indicates the sensitivity of the biological community to the toxic substance and illustrates the potential ecological risk caused by the overall contamination. The RI values were
TABle 2: Soil Environment Quality Risk Control Standard for Soil Contamination of Agricultural Land in China (GB15618-2018).

\begin{tabular}{lcccc}
\hline Heavy & \multicolumn{4}{c}{ Risk screening values for soil contamination of } \\
metals & \multicolumn{5}{c}{$\begin{array}{c}\text { agricultural land }(\mathrm{mg} / \mathrm{kg}) \\
\end{array}$} & $\mathrm{pH} \leq 5.5$ & $5.5<$ & $6.5<$ & $\mathrm{pH}>$ \\
$\mathrm{pH} \leq 6.5$ & $\mathrm{pH} \leq 7.5$ & 7.5 \\
\hline $\mathrm{Cr}$ & 250 & 250 & 300 & 350 \\
$\mathrm{Cd}$ & 0.3 & 0.4 & 0.6 & 0.8 \\
$\mathrm{~Pb}$ & 80 & 100 & 140 & 240 \\
$\mathrm{Cu}$ & 50 & 50 & 100 & 100 \\
$\mathrm{Zn}$ & 200 & 200 & 250 & 300 \\
\hline
\end{tabular}

classified into the following four risk levels: low risk $(\mathrm{RI} \leq 150)$, moderate risk $(150<\mathrm{RI} \leq 300)$, considerable risk $(300<\mathrm{RI} \leq 600)$, and high risk $(\mathrm{RI}>600)$ [29].

2.4.2. Accumulation Factor (AF) for Heavy Metals in Rice. The accumulation factor (AF) is defined as the ratio of the heavy metal concentration in plant roots to that in soil and is widely used to evaluate the ability of plants to accumulate heavy metals [31]. Additionally, the translocation factor (TF) is the ratio of the heavy metal concentration in the plant shoot to that in the plant root, which is also utilized to estimate the capacity of the plant to translocate heavy metals from the root to the shoot [32]. Their equations were as follows:

$$
\begin{gathered}
\mathrm{AF}=\frac{\text { Metal }_{\text {root }}}{\text { Metal }_{\text {soil }}}, \\
\mathrm{TF}=\frac{\text { Metal }_{\text {shoots }}}{\text { Metal }_{\text {root }}},
\end{gathered}
$$

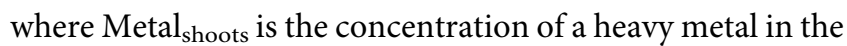
rice shoots (dry mass), Metal $_{\text {soil }}$ is the concentration of the heavy metal in the rhizosphere soil (dry soil), and Metal root $_{\text {is }}$ the concentration of the heavy metal in the rice roots.

2.4.3. In Vitro Simulation Test. All the soil samples used for the simulated in vitro digestion test were passed through a 100-mesh nylon sieve. The tested soil and digestion liquid were mixed at a ratio of $1: 100$ (solid to liquid). Then, the mixed solution was oscillated in a constant temperature water bath at $37^{\circ} \mathrm{C}$ and $100^{\circ} \mathrm{r} / \mathrm{min}$. After the extraction of gastric or gastrointestinal juices and centrifugation for $10 \mathrm{~min}$, the supernatant was passed through a $0.45 \mu \mathrm{m}$ filter membrane to be measured. The PBET method was used to simulate the extraction of gastric juice and intestinal juice. The gastric juice was a mixture that contained 1.25 g gastric 
protein, $0.50 \mathrm{~g}$ sodium malate, $0.5 \mathrm{~g}$ sodium citrate, $420 \mu \mathrm{L}$ lactic acid, and $500 \mu \mathrm{L}$ acetic acid. After complete dissolution, the volume of the mixed solution was brought to $1 \mathrm{~L}$, and simultaneously, the $\mathrm{pH}$ value of the solution was adjusted to 2.5 with dilute $\mathrm{HCl}$. After the extraction of the gastric juice, $\mathrm{NaHCO}_{3}$ powder was used to adjust the $\mathrm{pH}$ value of digestive juice to 7.0 , and then, bile salt $(52.5 \mathrm{mg})$ and trypsin $(15 \mathrm{mg})$ were successively added. Finally, the extraction of the intestinal juice was completed by shaking for 2 hours (Figure 1).

The bioavailability of the heavy metals $\mathrm{Cu}, \mathrm{Zn}, \mathrm{Pb}$, and $\mathrm{Cd}$ in the simulated gastric and intestinal stages was calculated as follows:

$$
\mathrm{BA}=\frac{C_{1} V_{1}}{C_{s} m_{s}} \times 100 \%,
$$

where BA is the bioavailability of specific heavy metals, \%; $C_{1}$ is the total soluble amount of specific heavy metals in the gastric or intestinal phase reaction solution of the in vitro simulation test, $\mathrm{mg} / \mathrm{L} ; V_{1}$ is the volume of reaction liquid, $L$; $C_{s}$ is the total concentration of a specific heavy metal in the soil samples, $\mathrm{mg} / \mathrm{kg}$; and $m_{\mathrm{s}}$ is the mass of the added soil sample, kg.

The average daily heavy metal intake through the soilhuman route is calculated as follows:

$$
W_{m}=C_{m} \times W_{\text {soil }},
$$

where $W_{\mathrm{m}}$ is the intake of heavy metals, $\mu \mathrm{g} / \mathrm{d} ; C_{\mathrm{m}}$ is the total concentration of a specific heavy metal in the soil samples, $\mu \mathrm{g} / \mathrm{g}$; and $W_{\text {soil }}$ is the daily average soil intake $(0.05 \mathrm{~g} / \mathrm{d}$ for adults and $0.2 \mathrm{~g} / \mathrm{d}$ for children).

The amount of heavy metals that can be absorbed in the body every day is calculated as follows:

$$
W_{A}=W_{m} \times \mathrm{BA},
$$

where $W_{A}$ is the amount of heavy metals that can be absorbed every day, $\mu \mathrm{g} / \mathrm{d} ; W_{m}$ is the intake of heavy metals, $\mu \mathrm{g} / \mathrm{d}$; and BA is the bioavailability of specific heavy metals, $\%$.

\section{Results and Discussion}

3.1. Level of Heavy Metal Pollution in Rice Soils. The $\mathrm{pH}$ values of the soils in the study area were between 7.93 and 8.14 and between 7.91 and 8.04 before sowing and at the harvesting period of rice, respectively. The most suitable soil $\mathrm{pH}$ value for raising rice seedlings is 4.5 to 5.5 [33]. Excessively acidic and alkaline soils are not conducive to the growth and development of seedling roots. One recommendation is that $\mathrm{pH}$ should be regulated by spraying the soil with brine two days before sowing if the $\mathrm{pH}$ value of the seedbed soil is greater than 6.5. Additionally, $50.00 \mathrm{~g}$ industrial sulfuric acid per square meter can be diluted 200 times with water and evenly sprayed on the seedbed [34]. The soil Eh ranged from -154.70 to $-144.00 \mathrm{mV}$ and -189.50 to $-180.60 \mathrm{mV}$ before rice sowing and at harvesting, respectively, which was attributed to intense reduction activity that will produce a large amount of sulfides. Zhang et al. [12] found that the Eh value ranged from $-182.00 \pm 12.85 \mathrm{mV}$ to $-478.00 \pm 8.01 \mathrm{mV}$ during the whole growth period in the $0-20 \mathrm{~cm}$ soil layer. During the rice growing period, because of the long-term waterlogging and plowing of the topsoil as well as the accumulation and decomposition of organic fertilizer and stubble, soil oxidation-reduction alternations occur periodically, which change the soil redox potential. If the Eh value remains below $-100 \mathrm{mV}$ for a long time, the rice can be seriously damaged or even die. Therefore, it is necessary to drain and dry the field in time to improve its Eh value. The organic matter contents of the soils in this study were $23.64-26.24 \mathrm{~g} / \mathrm{kg}$ and $47.13-54.15 \mathrm{~g} / \mathrm{kg}$ before sowing and at the harvesting period of rice, respectively. The organic matter contents of the former and latter were at the uppermiddle and high levels, respectively, which may have been caused by fertilization (the second National Soil Census and Classification Standard of China). The concentrations of total phosphorus were $0.47-0.89 \mathrm{~g} / \mathrm{kg}$ before the sowing period and $0.55-1.01 \mathrm{~g} / \mathrm{kg}$ at the rice harvesting period. $\mathrm{Li}$ et al. [35] reported the effective phosphorus and the total phosphorus in paddy soil in the distribution region of Nostoc sphaeroides. The content of the total phosphorus in the surface layer soil was $0.28 \sim 1.36 \mathrm{~g} / \mathrm{kg}$, which was consistent with the levels in this study. It was found that there was no obvious change in the total phosphorus content of soils between the two growth periods of rice. For the total potassium contents of the soils, the values were $9.71-27.28 \mathrm{~g} / \mathrm{kg}$ before the sowing period and $2.43-7.84 \mathrm{~g} / \mathrm{kg}$ at the harvesting period, indicating the low total potassium content in the study area. Xu et al. [36] studied the characteristics of and spatial-temporal variations in soil fertility in paddy fields in the river-network plains of Zhejiang. On average, available $P$ and $K$ were $168.02 \%$ and $12.52 \%$ higher, respectively, than the levels in the second national soil survey. However, a large proportion of the soil still showed deficiencies in phosphorus and potassium.

For the heavy metals $(\mathrm{Pb}, \mathrm{Cd}, \mathrm{Cu}, \mathrm{Zn}$, and $\mathrm{Cr})$ and metalloids ( $\mathrm{Hg}$ and $\mathrm{As}$ ), the $E_{r}^{i}$ values of $\mathrm{Cd}$ were the highest during the two growth periods; this was attributed to the higher ecotoxicity of $\mathrm{Cd}$ than of the other studied elements and the level of Cd, which slightly exceeded the national standard for $\mathrm{Cd}$ content. In both growth periods, the order of $E_{r}^{i}$ values was $E_{r}^{i}(\mathrm{Cd})>E_{r}^{i}(\mathrm{Hg})>E_{r}^{i}(\mathrm{As})>E_{r}^{i}(\mathrm{~Pb})>E_{r}^{i}(\mathrm{Cu})>E_{r}^{i}(\mathrm{Cr})>E_{r}^{i}$ $(\mathrm{Zn})$ (Figures 2 and 3 ). However, the low RI values for the heavy metals (91.63 and 30.29 at the two stages, respectively) demonstrated the low risk in the study areas. Surprisingly, the $\mathrm{Cd}$ concentration in the soil at the harvesting period of rice was significantly lower than that before the sowing period, which may be due to the $\mathrm{Cd}$ in the rhizosphere soil being adsorbed by the rice. In the agricultural soils of Nanjing, Chen et al. [37] found that $\mathrm{Cd}$ was more easily enriched in rice than $\mathrm{As}, \mathrm{Hg}, \mathrm{Pb}$, $\mathrm{Cr}, \mathrm{Cu}$, and $\mathrm{Zn}$. The results showed that $9.09 \%$ of the soil exceeded the standard level for Cd content, and most of the Cdpolluted samples were from Suzhou, Zhenjiang, and Changzhou according to Maximum levels of contaminants in Foods Standard (GB 2762-2005). 4.55\% of rice grains exceeded the standard level for $d$ content, and most of the polluted samples were from Suzhou and Wuxi; impact factors on $\mathrm{Cd}$ accumulation in rice were soil $\mathrm{pH}$ and contents of total organic 


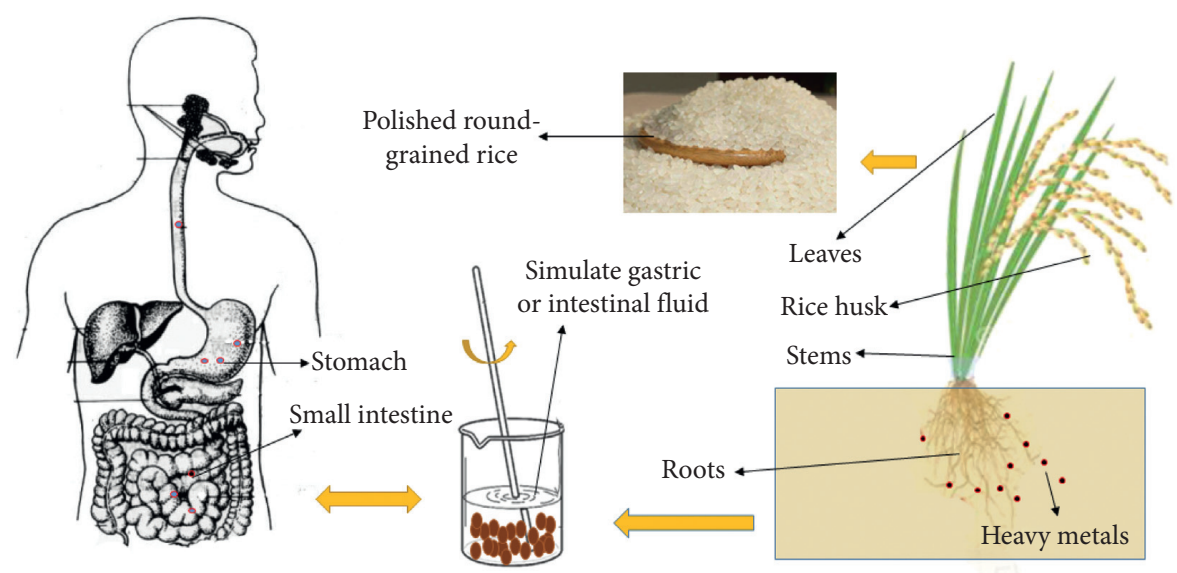

FIgURE 1: The sketch map of in vitro simulation test: (a) harvest stage of rice; (b) in vitro simulation test.

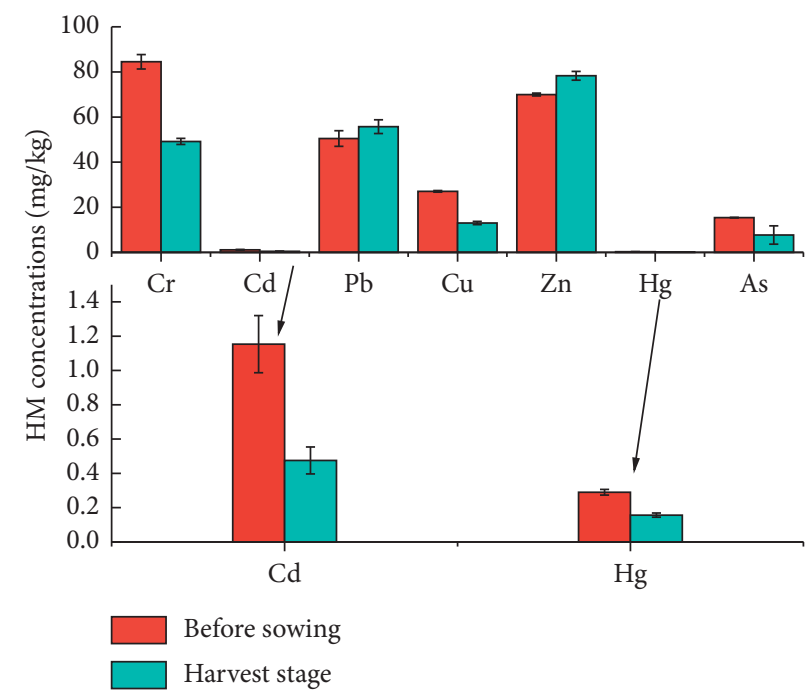

FIgURE 2: Concentration of heavy metals in soil at the different growth periods of rice.

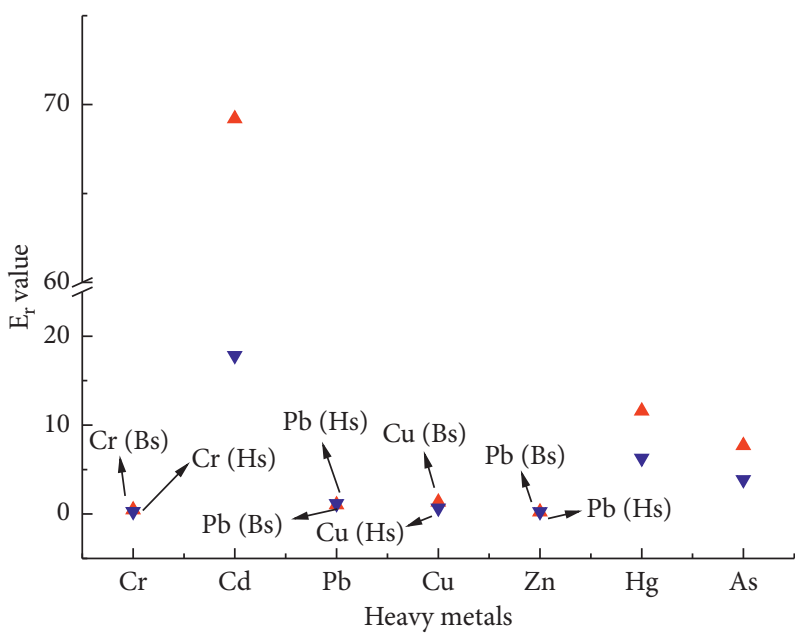

$\Delta$ Before sowing

v Harvesting stage

FIgURE 3: $E_{r}^{i}$ values of heavy metals in soil at the two growth periods of rice. 
carbon. Zhao et al. [38] reported that some studied areas showed potential contamination by heavy metals, especially by $\mathrm{Cd}$, in a paddy field of a soil-rice system. The accumulation of these metals may be due to industrialization, agricultural chemicals, and other human activities. Shi et al. [39] showed that approximately 44 and $60 \%$ of soil samples exceeded the Chinese Soil Environmental Quality Standards for $\mathrm{Cu}$ and Cd, respectively. There was a significant positive correlation between the total $\mathrm{Cu}$ and $\mathrm{Zn}$ contents in the soil and the application rate of pig manure. Zhang et al. [12] demonstrated that the $E_{r}^{i}$ values of $\mathrm{Cd}$ in two soil profiles during rice presowing, emergence, and tillering exceeded 40 , which indicated a moderate potential ecological risk in soils during these three stages.

Figure 4(a) shows the five species (residual, organic matterbound, iron-manganese oxide-bound, exchangeable, and carbonate-bound) of heavy metals in soils before the sowing stage of rice. For Cr, in both growth periods (before sowing and at harvesting), the order of chemical speciation of $\mathrm{Cr}$ was as follows: residual > organic matter-bound > iron-manganese oxide-bound $>$ exchangeable $>$ carbonate-bound (Figure 4(b)). The residual heavy metals refer to the metal ions bound in the soil silicoaluminate mineral lattice, which are difficult to release under normal conditions and are not easily absorbed by plants [40]. Similarly, the percentages of residual As, $\mathrm{Zn}$, and $\mathrm{Hg}$ were higher than those of the other species, which implied that $\mathrm{Cr}$, As, and $\mathrm{Hg}$ were taken up by rice only slightly in this study. However, the percentage of residual Cd decreased significantly and the percentage of iron-manganese oxide-bound $\mathrm{Cd}$ increased between the two growth stages. Similar phenomena were also found for $\mathrm{Pb}$ and $\mathrm{Cu}$. The iron-manganese oxidebound fraction is adsorbed by the specific exchange position of iron-manganese oxides or clay minerals in the soil [41]. It cannot be exchanged with a neutral salt solution but can only be replaced by metal ions with similar or stronger affinity. Additionally, the $\mathrm{pH}$ value and redox conditions in the soil have an important influence on the iron-manganese oxidebound fraction [42]. It is beneficial to the formation of ironmanganese oxide bonds if the $\mathrm{pH}$ value and redox potential are high, which reflects the way in which environmental pollution is caused by human activities. Overall, the contents of the ironmanganese oxide-bound fraction in soils before rice sowing were higher than those at the rice harvesting stage, which may have been caused by the use of fertilizer in the rice-planting process. In addition, organic matter became bound to heavy metals due to the presence of various organic substances in the soil, e.g., animal and plant residues, humus and mineral particles, and heavy metals in the soils [43]. The content of organic matter bound to heavy metals reflects the activities of aquatic organisms and the results of human discharge of organic-rich wastewater [44].

Notably, the carbonate-bound fraction was the most sensitive to the soil environmental conditions, especially the $\mathrm{pH}$ value. This fraction releases easily and enters the environment when the $\mathrm{pH}$ value decreases. In contrast, the increase in $\mathrm{pH}$ value was beneficial to the formation of the carbonate-bound fraction, which is formed by the coprecipitation of heavy metals on carbonate minerals in soil. In both growth periods, the contents of carbonate-bound heavy metals were relatively lower than those of the other fractions. Fortunately, the contents of the exchangeable fraction of heavy metals in both growth periods were the lowest. The exchangeable fraction is made up of metals adsorbed onto clay, humus, and other components. This fraction is sensitive to environmental change, transfers and transforms easily, and can be absorbed by plants. The content of this fraction reflects the recent impacts of human pollution and its biological toxicity; the low levels in this study imply that the heavy metals investigated in this study are not easily adsorbed by local rice and that the farmland is not polluted by heavy metals. Li et al. [45] suggested that the main factors affecting the distribution of $\mathrm{Pb}$ and $\mathrm{Cd}$ were the soil $\mathrm{pH}$, organic matter content, humic acid composition, and calcium carbonate content. Nevertheless, Zhen et al. [46] found that the available state of $\mathrm{Hg}$ was mainly related to the contents of sulfur, chloride, and organic fertilizer in soils. Yu and Liu [47] demonstrated that Cr mainly accumulated in the surface layer and the plow layer at $20-40 \mathrm{~cm}$, while there was no obvious $\mathrm{Cr}$ accumulation in the lower soil. Moreover, they found that $\mathrm{Cr}$ was not mobile in the soil and was not easily taken up by plants. Their conclusions are consistent with the findings of this study.

\subsection{Accumulation and Transfer Factors in the Rice-Soil} System. Table 3 shows the concentrations of the heavy metals in different tissues of rice and their AF and TF values. The order of $\mathrm{Cr}$ content in the different tissues of rice was root $>$ leaves $>$ grain $>$ stem $>$ rice husk $>$ polished round-grained rice. The $\mathrm{AF}$ and $\mathrm{TF}$ values of $\mathrm{Cr}$ were 0.0403 and 0.2940 , respectively. The alkaline soil in the study areas can significantly affect the speciation of $\mathrm{Cr}$ in soils. The higher $\mathrm{pH}$ values of soils in the study areas can significantly affect the speciation of Cr. Generally, the main chemical species of $\mathrm{Cr}$ is $\mathrm{Cr}(\mathrm{VI})$ in normal soil environments. The lower $\mathrm{pH}$ values in soils are helpful for transforming $\mathrm{Cr}(\mathrm{VI})$ into stable $\mathrm{Cr}$ (III), which can reduce the migration capacity and toxicity of $\mathrm{Cr}$ in soils. In contrast, a higher $\mathrm{pH}$ value in soils is conducive to the formation of $\mathrm{Cr}(\mathrm{IV})$, especially in alkaline soils. The process of $\mathrm{Cr}$ (III) oxidation to $\mathrm{Cr}(\mathrm{IV})$ is slow, and the $\mathrm{pH}$ value of soils must exceed 5 for the reaction to occur. $\mathrm{Cr}$ (III) is the most stable state under reduction conditions, and $\mathrm{Cr}(\mathrm{OH})^{2+}$ and its cation are the main species at $\mathrm{pH}$ values between 4 and 8 in soils. $\mathrm{Cr}(\mathrm{VI})$ is the most stable state in oxidation environments and at $\mathrm{pH}$ values of 2-14 in soils [48]. Additionally, organic matter is also an important factor influencing the change in $\mathrm{Cr}$ speciation. $\mathrm{Cr}(\mathrm{VI})$ can be reduced with the organic matter oxidation, and thus, its bioavailability and toxicity decrease. Generally, the $\mathrm{Cr}$ concentration in roots is 10-100 times than that in other tissues, which was consistent with the results of this study. Plants can be damaged when the total $\mathrm{Cr}$ content is between 75 and $100 \mathrm{mg} / \mathrm{kg}$ or higher. However, it is currently unclear which valence states of $\mathrm{Cr}$ are easily absorbed to rice [48]. In this study, the total content of $\mathrm{Cr}$ did not exceed the standard limit value, and the values were well below $350 \mathrm{mg} / \mathrm{kg}$ (GB15618-2018). 


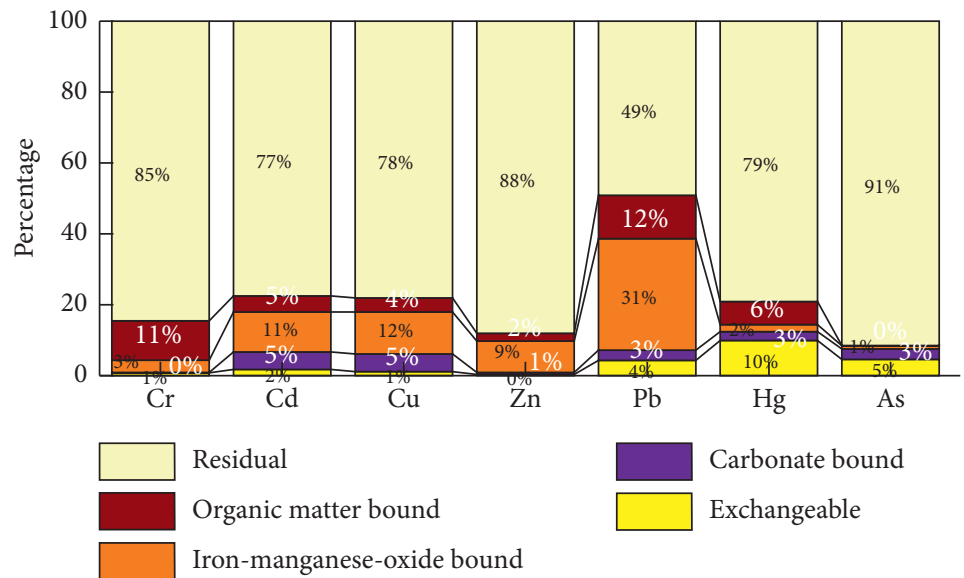

(a)

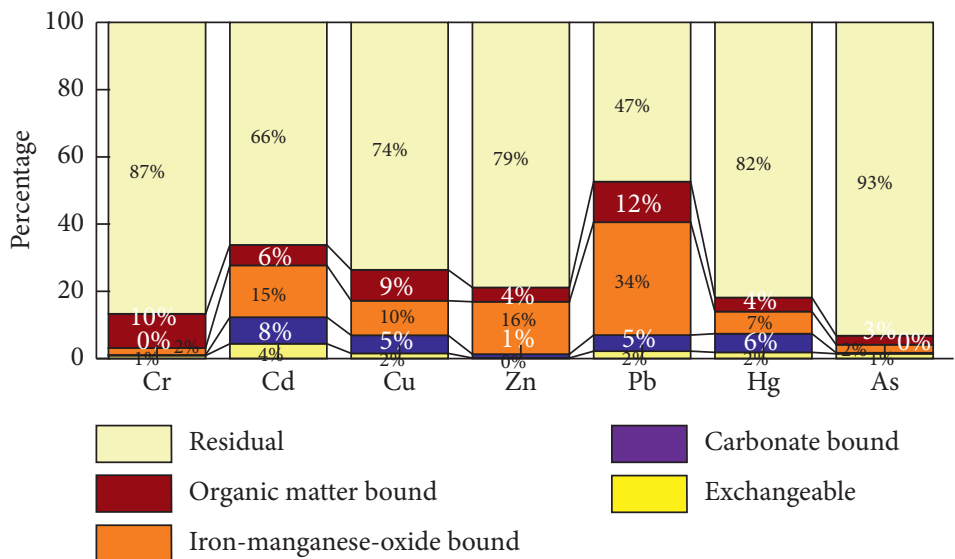

(b)

FIGURE 4: Concentration of heavy metal speciation in soil at the before sowing (a) and harvesting (b) periods of rice.

TABLE 3: Concentration of heavy metals of roots, stem, leaves, grain, rice husk, and polished round-grained rice.

\begin{tabular}{|c|c|c|c|c|c|c|c|c|}
\hline & $\begin{array}{c}\text { Root } \\
(\mathrm{mg} / \mathrm{kg})\end{array}$ & $\begin{array}{c}\text { Stem } \\
(\mathrm{mg} / \mathrm{kg})\end{array}$ & $\begin{array}{l}\text { Leaves } \\
(\mathrm{mg} / \mathrm{kg})\end{array}$ & $\begin{array}{c}\text { Grain } \\
(\mathrm{mg} / \mathrm{kg})\end{array}$ & $\begin{array}{c}\text { Rice husk } \\
(\mathrm{mg} / \mathrm{kg})\end{array}$ & $\begin{array}{l}\text { Polished round-grained } \\
\text { rice }(\mathrm{mg} / \mathrm{kg})\end{array}$ & AF value & TF value \\
\hline $\mathrm{Cr}$ & $1.982 \pm 0.075$ & $0.4320 \pm 0.375$ & $0.5826 \pm 0.018$ & $0.5321 \pm 0.062$ & $0.2179 \pm 0.037$ & $0.2099 \pm 0 . .034$ & 0.04 & 0.29 \\
\hline $\mathrm{Cd}$ & $1.500 \pm 0.125$ & $0.0930 \pm 0.018$ & $0.1871 \pm 0.025$ & $0.1698 \pm 0.004$ & $0.0770 \pm 0.009$ & $0.0928 \pm 0.008$ & 3.16 & 0.12 \\
\hline $\mathrm{Pb}$ & $13.75 \pm 0.750$ & $3.191 \pm 0.153$ & $1.431 \pm 0.206$ & $3.569 \pm 0.370$ & $1.354 \pm 0.284$ & $2.216 \pm 0.553$ & 0.25 & 0.10 \\
\hline $\mathrm{Zn}$ & $22.24 \pm 0.588$ & $13.29 \pm 1.595$ & $13.80 \pm 0.740$ & $24.060 \pm 1.522$ & $8.614 \pm 0.940$ & $15.45 \pm 0.942$ & 0.28 & 0.62 \\
\hline $\mathrm{Cu}$ & $5.524 \pm 0.802$ & $1.129 \pm 0.128$ & $3.145 \pm 0.127$ & $3.132 \pm 0.021$ & $1.509 \pm 0.038$ & $1.623 \pm 0.048$ & 0.42 & 0.57 \\
\hline $\mathrm{Hg}$ & $0.0042 \pm 0.004$ & $0.0018 \pm 0.005$ & $0.0024 \pm 0.006$ & $0.0015 \pm 0.010$ & $0.0021 \pm 0.012$ & 0.0019 & 0.03 & 0.57 \\
\hline As & $0.5154 \pm 0.091$ & $0.0117 \pm 0.074$ & $0.2145 \pm 0.096$ & $0.2754 \pm 0.074$ & $0.3014 \pm 0.845$ & 0.4245 & 0.07 & 0.42 \\
\hline
\end{tabular}

All values are mean of three replicates $(n=3)$.

The main order of $\mathrm{Cd}$ accumulation in different tissues was root $>$ leaves $>$ stem. The concentration of $\mathrm{Cd}$ in rice roots has been found to be generally $5-63 \mathrm{mg} / \mathrm{kg}$ in farmland polluted by heavy metals $[49,50]$. Although the Cd content in this study was $1.500 \mathrm{mg} / \mathrm{kg}$, the risk from Cd was low according to the potential ecological hazard index. The AF and TF values of $\mathrm{Cd}$ were 3.158 and 0.1247 , respectively. Excessive Cd accumulation in the kidney causes damage to the urinary system. The main manifestation of renal damage is proximal tubular dysfunction, which is not fatal but may slightly affect life expectancy. The $\mathrm{pH}$ value is one of the most important factors affecting $\mathrm{Cd}$ absorption by rice roots. It was reported that the quality of $\mathrm{Cd}$ absorbed by plants was negatively correlated with the $\mathrm{pH}$ value of the soil within a certain range of $\mathrm{pH}$ values. In addition, $\mathrm{Cd}$ mainly exists in its water-soluble form. On the root surface, $\mathrm{Cd}$ ions compete with $\mathrm{H}^{+}$for binding sites. The root surface will release positive ion-binding sites with the increase in $\mathrm{pH}$ value, increasing $\mathrm{Cd}$ binding and absorption [51]. The redox value (Eh) is also one of the main factors affecting the 
bioavailability of $\mathrm{Cd}$ in soil. It was reported that the content of water-soluble $\mathrm{Cd}$ in soil, the total amount of $\mathrm{Cd}$ absorbed by rice, and the amount of $\mathrm{Cd}$ above ground increased with the increase in the Eh value in paddy fields. When the soil was experiencing reduction conditions, the quantity of sulfur reduced to $\mathrm{S}^{2-}$ increased with the decrease in redox potential and precipitated with $\mathrm{Fe}, \mathrm{Cd}$, and $\mathrm{Hg}$ ions in the soil, thus reducing the concentration of heavy metal elements in the soil solution [52]. This may explain why the residual $\mathrm{Cd}$ was lower and its TF values were higher than those of the other heavy metals (Figure 5) [53].

The order of $\mathrm{Pb}$ accumulation in the different tissues of rice was root $>$ stem $>$ leaves. Its $\mathrm{AF}$ and $\mathrm{TF}$ values were relatively lower than those of the other heavy metals, which may have been due to the lower mobility of $\mathrm{Pb}$ in the soil and the few exchangeable states of lead in the soil. $\mathrm{Pb}$ can result in toxic symptoms when plants are exposed to lead stress, e.g., changes in membrane permeability, disruptions to enzyme activity, disruptions in mitosis, and DNA damage. It was reported that the contribution of $\mathrm{Pb}$ adsorption and absorption to the accumulation of lead in plants was much greater than that of root absorption and transportation to the upper parts of the soil in some areas with high concentrations of atmospheric $\mathrm{Pb}$ [54]. However, a similar phenomenon was not found in this study, which may be due to the decrease in the $\mathrm{Pb}$ concentration in the local atmosphere. The $\mathrm{Pb}$ sources in this study were primarily automobile exhaust and fertilizer application [55]. The absorption of $\mathrm{Pb}$ by plant roots is carried out by heteroplastic and symplastic methods. $\mathrm{Pb}$ is absorbed by the roots of rice in the soil by the absorption of dissolved $\mathrm{Pb}$ ions in the soil solution; hence, the content of the exchangeable state of $\mathrm{Pb}$ before the sowing period of rice was higher than that at the harvesting stage of rice. In addition to the heteroplastic pathway, the rice roots can also absorb $\mathrm{Pb}$ through the symplastic pathway [56], e.g., Ca channels [57], endocytosis [58], calmodulin [59], and some low-affinity cation transporters [60]. The transfer of $\mathrm{Pb}$ absorbed by plant roots to the aboveground plant parts is mainly controlled by two processes, i.e., transfer from xylem parenchyma cells to vessels and transport in vessels, and the latter is mainly affected by root pressure and transpiration flow. Therefore, most of the $\mathrm{Pb}$ absorbed by roots (approximately $95 \%$ or more) accumulates in root tissues, and only a small amount of $\mathrm{Pb}$ is transported to and accumulates in the aboveground plant parts by the symplastic pathway, which is consistent with the findings of this study [61-63].

Because the $\mathrm{AF}$ and $\mathrm{TF}$ values of $\mathrm{Zn}, \mathrm{Cu}, \mathrm{Hg}$, and As were similar, they are discussed simultaneously in this work. The TF values of $\mathrm{Zn}, \mathrm{Cu}, \mathrm{Hg}$, and As were 0.6205, 0.5693, 0.5714, and 0.4162 , respectively. The AF values of $\mathrm{Zn}, \mathrm{Cu}, \mathrm{Hg}$, and As were $0.2841,0.4238,0.0268$, and 0.0668 , respectively, and $\mathrm{Cu}$ had the highest $\mathrm{AF}$ value. $\mathrm{Cu}$ is a necessary micronutrient element for the normal growth and development of rice and a cofactor of many enzymes [64]. It is very important in many biological processes, including photosynthetic and respiratory electron transport and cell wall remodeling. Lower concentrations of $\mathrm{Cu}$ can promote the growth and development of rice. Insufficient $\mathrm{Cu}$ affects the growth and

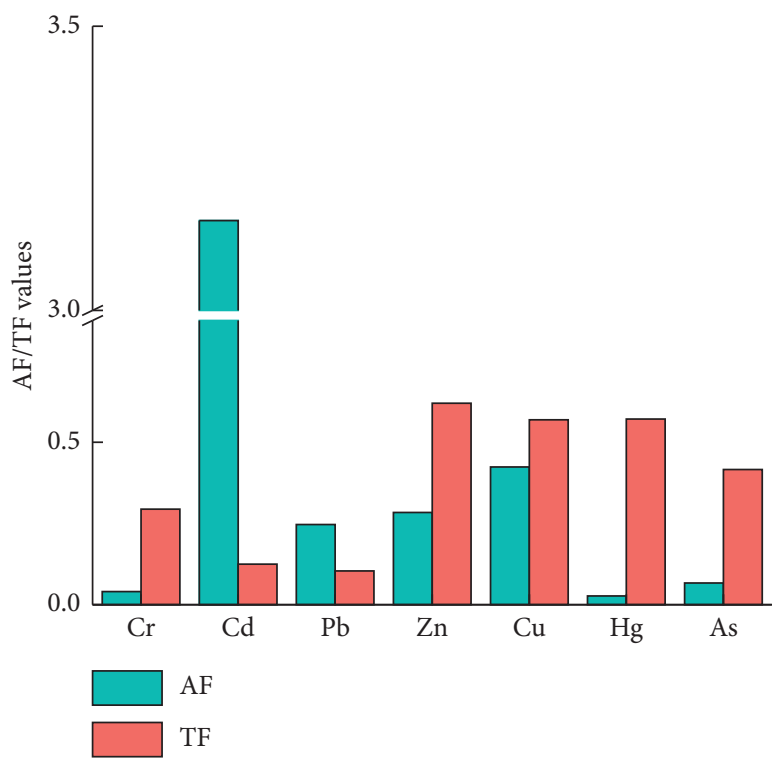

FIGURE 5: AF and TF values of heavy metals at the harvesting period of rice.

development of rice reproductive organs. However, the structure and function of the rice cell membrane can be destroyed when the concentration of $\mathrm{Cu}$ exceeds the threshold value for rice growth, affecting the permeability of the rice cell membrane and damaging the antioxidant enzyme system and chloroplast structure of the plant; thus, the development of rice is inhibited [63]. Fortunately, the contents of $\mathrm{Cu}$ in the soil and plants were in the normal range according to the analysis in this study. $\mathrm{Zn}$ is also one of the essential microelements in plants that has important physiological and nutritional functions. However, excessive $\mathrm{Zn}$ can damage the root system of rice and hinder the growth of the root system [65]. It was reported that $\mathrm{Zn}$ is a transition element with $3 d$ electrons, which have special properties and efficiency for catalysis and magnetism, and the electronic arrangement of $\mathrm{Zn}$ is the source of its biological toxicity. In addition, brown spots and necrosis on the ground are sometimes observed under high $\mathrm{Zn}$ stress; nevertheless, this situation was not observed in this study.

Finally, although the toxicity of $\mathrm{Hg}$ and As was greater than that of the other studied heavy metals, their contents in soil and rice were comparatively low, rendering them less influential to the local population. Wang et al. [66] reported that the order of the uptake and accumulation of these 5 heavy metals in rice was $\mathrm{Zn}>\mathrm{Pb}>\mathrm{Cr}>\mathrm{Cu}>$ As. The contents of heavy metals in rice roots were 1.23-43.76 times higher than those in the stems and leaves. Lu et al. [67] found that the concentrations of $\mathrm{Cd}$ and $\mathrm{Pb}$ in paddy soils from industrial areas were significantly higher than those in soils from township areas and clean areas; however, these patterns were not observed in the $\mathrm{Cd}$ and $\mathrm{Pb}$ concentrations in the rice grains grown in these areas. The mean transfer factor of $\mathrm{Cd}$ was 0.742 , which was the highest of all the selected metals. Chen et al. [68] demonstrated that the transfer ability of heavy metals in the soil-rice system was stronger than those in the soil-wheat and soil-canola systems. The wheat 
showed a strong capacity to transfer $\mathrm{Zn}, \mathrm{Cu}$, and $\mathrm{Cd}$ from roots to the grain, while canola restricted the intake of $\mathrm{Cu}$ and Cd. Soil $\mathrm{pH}$ and total organic matter are major factors influencing the transfer of metals from soil to rice. Overall, the order of $\mathrm{AF}$ and $\mathrm{TF}$ values was $\mathrm{Cd}(3.16)>\mathrm{Cu}(0.42)>\mathrm{Zn}$ $(0.28)>\mathrm{Pb} \quad(0.25)>\mathrm{As}(0.07)>\mathrm{Cr}(0.04)>\mathrm{Cr}(0.03)$ and root $>$ stem $>$ leaves in this study, respectively.

3.3. In Vitro Simulation Test with $\mathrm{Cd}, \mathrm{Pb}, \mathrm{Cu}$, and $\mathrm{Zn}$. The long-term intake of heavy metal-contaminated soil through absorption and accumulation in the human body will have adverse effects on the health of adults and children. Because Cd easily accumulates in rice, an in vitro simulation method was employed to simulate the intake and bioavailability of $\mathrm{Cd}$ through the soil-oral cavity route. Tables 4 and 5 show the amount of heavy metal Cd consumed by adults and children through the soil-oral cavity route. In this study, only the per tolerable weekly intake (PTWI) values for $\mathrm{Pb}$ and $\mathrm{Cd}$ were considered. The WHO (World Health Organization) recommends that the PTWI of Cd is $7.00 \mu \mathrm{g} / \mathrm{kg}$ and the PTWI of $\mathrm{Pb}$ is $50.00 \mu \mathrm{g} / \mathrm{kg}$ (adults) and $25.00 \mu \mathrm{g} / \mathrm{kg}$ (children). For adults with a body mass of $60 \mathrm{~kg}$, the intake of Cd should not exceed $60.00 \mu \mathrm{g} / \mathrm{d}$, and the intake of $\mathrm{Pb}$ should not exceed $428.57 \mu \mathrm{g} / \mathrm{d}$. For children with a body mass of $30 \mathrm{~kg}$, the intake of Cd should not exceed $30 \mu \mathrm{g} / \mathrm{d}$, and the intake of $\mathrm{Pb}$ should not exceed $107.14 \mu \mathrm{g} / \mathrm{d}$ [69]. The content ranges of Cd, $\mathrm{Pb}, \mathrm{Cu}$, and $\mathrm{Zn}$ in the daily intake of adults through the soiloral cavity route were $0.03-0.08 \mu \mathrm{g} / \mathrm{d}, 2.37-2.82 \mu \mathrm{g} / \mathrm{d}$, $1.3-2.34 \mu \mathrm{g} / \mathrm{d}$, and $2.01-4.76 \mu \mathrm{g} / \mathrm{d}$, respectively. Compared with the PTWI, the amount of $\mathrm{Pb}$ and $\mathrm{Cd}$ for the daily intake of adults through the soil-oral cavity route in the study area did not exceed the daily tolerance for $\mathrm{Pb}$ and $\mathrm{Cd}$ proposed by the WHO. The content ranges of $\mathrm{Cd}, \mathrm{Pb}, \mathrm{Cu}$, and $\mathrm{Zn}$ in the daily intake of children through the soil-oral cavity route were $0.18-0.32 \mu \mathrm{g} / \mathrm{d}, \quad 7.15-13.52 \mu \mathrm{g} / \mathrm{d}, \quad 4.46-6.46 \mu \mathrm{g} / \mathrm{d}$, and $12.55-15.17 \mu \mathrm{g} / \mathrm{d}$, respectively. Their values still did not exceed the limit values for $\mathrm{Pb}$ and $\mathrm{Cd}$ proposed by the WHO. Chen et al. [70] performed a human health risk assessment on $\mathrm{Cd}$ in vegetables and evaluated the remediation effect on Cdpolluted soil using an in vitro simulation test. According to the in vitro simulation test, the bioavailable $\mathrm{Cd}$ content in leek and rape reached 0.027 and $0.039 \mathrm{mg} / \mathrm{kg}$ fresh weight, respectively, indicating that $\mathrm{Cd}$ in leek is more available to humans than that in rape. The carcinogenic risk of $\mathrm{Cd}$ to the human body was observed for both vegetables based on the health risk assessment. Moreover, the carcinogenic risk to children aged $0 \sim 6$ years was higher than that to adults aged $>18$ years. Lan et al. [71] performed a health risk assessment of heavy metals in rice grains from a mining-impacted area in south Hunan with an in vitro simulation method. Both the gastric phase and intestinal stage stimulations showed that the average bioavailability of $\mathrm{Pb}, \mathrm{Zn}, \mathrm{Cu}, \mathrm{Cd}$, and $\mathrm{As}$ in rice grains was much higher in rice from the mining-impacted area than in rice from the noncontaminated area, with higher bioavailability at the simulated gastric phase than at the simulated intestinal stage. The bioavailability of $\mathrm{Cd}$ at the simulated gastric phase was 3.11 times (for an adult) and 4.42 times (for a child) the biologically tolerable weekly intake. At
TABLE 4: Bioavailability of simulated intestinal and gastric stages.

\begin{tabular}{lcccccccc}
\hline \multirow{2}{*}{ Target } & \multicolumn{3}{c}{ Simulated gastric } & \multicolumn{4}{c}{ Simulated intestinal } \\
& absorption stage (\%) & \multicolumn{3}{c}{ absorption stage (\%) } \\
& $\mathrm{Cd}$ & $\mathrm{Pb}$ & $\mathrm{Cu}$ & $\mathrm{Zn}$ & $\mathrm{Cd}$ & $\mathrm{Pb}$ & $\mathrm{Cu}$ & $\mathrm{Zn}$ \\
\hline Maximum values & 25.15 & 0.51 & 7.05 & 2.15 & 5.15 & 0.14 & 3.87 & 0.95 \\
Minimum values & 20.42 & 0.39 & 6.15 & 1.33 & 4.35 & 0.07 & 2.21 & 0.28 \\
Average values & 22.78 & 0.45 & 6.60 & 1.74 & 4.75 & 0.11 & 3.04 & 0.62 \\
\hline
\end{tabular}

TABle 5: Amount of heavy metals ingested by adults and children through the soil-human route.

\begin{tabular}{lccccc}
\hline \multirow{2}{*}{ Age } & \multirow{2}{*}{ Target } & \multicolumn{4}{c}{ Heavy metal intake $(\mu \mathrm{g} / \mathrm{d})$} \\
& & $\mathrm{Cd}$ & $\mathrm{Pb}$ & $\mathrm{Cu}$ & $\mathrm{Zn}$ \\
\hline \multirow{4}{*}{ Adult } & Maximum values & 0.08 & 2.82 & 2.34 & 4.76 \\
& Minimum values & 0.03 & 2.37 & 1.30 & 2.01 \\
& Average values & 0.06 & 2.60 & 1.82 & 3.38 \\
& PTWI $^{*}$ & 60.00 & 428.57 & - & - \\
\hline \multirow{4}{*}{ Children } & Maximum values & 0.32 & 13.52 & 6.46 & 15.17 \\
& Minimum values & 0.18 & 7.15 & 4.46 & 12.55 \\
& Average values & 0.25 & 10.34 & 5.46 & 13.86 \\
& PTWI* $^{*}$ & 30.00 & 107.14 & - & - \\
\hline
\end{tabular}

${ }^{*}$ Conversion of weekly tolerance to daily tolerance.

the simulated intestinal stage, the bioavailability of $\mathrm{Pb}, \mathrm{Cd}$, and As in rice grains from the mining-impacted area was lower than the tolerable weekly intake for adults but exceeded that for children. These findings show that consuming rice grains from mining-impacted areas poses health risks to human beings, especially children.

The absorption function of the human digestive tract to food is mainly reflected in the small intestine stage. The effective proportion of the soil heavy metals in the intestine compared with that in the stomach is an important indicator across the whole simulated digestion experiment. The results can effectively express the bioavailability of heavy metals in soil through oral intake or can be understood as the maximum amount that may be absorbed by the body. Although bioavailability does not fully indicate the actual amount absorbed by the small intestine into the human circulatory system, it can be used as a reference for health risk assessment. Table 5 shows the bioavailability of $\mathrm{Cd}, \mathrm{Pb}$, $\mathrm{Cu}$, and $\mathrm{Zn}$ in the soil of the study area at the different digestion stages of the in vitro digestion simulation. For adults, the average bioavailability of $\mathrm{Cd}, \mathrm{Pb}, \mathrm{Cu}$, and $\mathrm{Zn}$ from the soil in the study area was $0.013 \mu \mathrm{g} / \mathrm{d}, 0.012 \mu \mathrm{g} / \mathrm{d}$, $0.12 \mu \mathrm{g} / \mathrm{d}$, and $0.059 \mu \mathrm{g} / \mathrm{d}$ in the simulated gastrointestinal stage, respectively (Table 6). Similarly, for children, the average bioavailability of $\mathrm{Cd}, \mathrm{Pb}, \mathrm{Cu}$, and $\mathrm{Zn}$ from the soil in the study area was $0.056 \mu \mathrm{g} / \mathrm{d}, 0.047 \mu \mathrm{g} / \mathrm{d}, 0.36 \mu \mathrm{g} / \mathrm{d}$, and $0.24 \mu \mathrm{g} / \mathrm{d}$ in the simulated gastrointestinal stage, respectively. In both adults and children, the amount of $\mathrm{Pb}$ and $\mathrm{Cd}$ in the daily intake through the soil-oral cavity route in the study area did not exceed the daily tolerance for $\mathrm{Pb}$ and $\mathrm{Cd}$ proposed by the WHO. Wu et al. [72] determined the bioaccessibility and health risk of heavy metals in topsoil at primary schools in a coal mining city. The bioavailability amounts of heavy metals in the stomach stage were 4.88 , $2.10,4.98,6.31,5.73$, and $13.51 \mathrm{mg} / \mathrm{kg}$, respectively, while 
TABLE 6: Bioavailability of heavy metals in different digestive stages of adults and children.

\begin{tabular}{|c|c|c|c|c|c|c|c|c|c|}
\hline \multirow{2}{*}{ Age } & \multirow{2}{*}{ Target } & \multicolumn{4}{|c|}{ Simulated gastric absorption stage (\%) } & \multicolumn{4}{|c|}{ Simulated intestinal absorption stage (\%) } \\
\hline & & $\mathrm{Cd}$ & $\mathrm{Pb}$ & $\mathrm{Cu}$ & $\mathrm{Zn}$ & $\mathrm{Cd}$ & $\mathrm{Pb}$ & $\mathrm{Cu}$ & $\mathrm{Zn}$ \\
\hline \multirow{4}{*}{ Adult } & Maximum values & $2.12 \mathrm{E}-02$ & $1.43 \mathrm{E}-02$ & $1.65 \mathrm{E}-01$ & $1.02 \mathrm{E}-01$ & 4.34E-03 & $4.02 \mathrm{E}-03$ & $9.07 \mathrm{E}-02$ & $4.50 \mathrm{E}-02$ \\
\hline & Minimum values & $6.15 \mathrm{E}-03$ & $9.35 \mathrm{E}-03$ & $8.00 \mathrm{E}-02$ & 2.67E-02 & $1.31 \mathrm{E}-03$ & $1.76 \mathrm{E}-03$ & $2.88 \mathrm{E}-02$ & $5.73 \mathrm{E}-03$ \\
\hline & Average values & $1.30 \mathrm{E}-02$ & $1.17 \mathrm{E}-02$ & $1.20 \mathrm{E}-01$ & 5.87E-02 & $2.72 \mathrm{E}-03$ & $2.81 \mathrm{E}-03$ & $5.54 \mathrm{E}-02$ & $2.08 \mathrm{E}-02$ \\
\hline & PTWI* & 30.00 & 107.14 & - & - & 30.00 & 107.14 & - & - \\
\hline \multirow{4}{*}{ Children } & Maximum values & 7.93E-02 & $6.86 \mathrm{E}-02$ & $4.55 \mathrm{E}-01$ & $3.25 \mathrm{E}-01$ & $1.62 \mathrm{E}-02$ & $1.92 \mathrm{E}-02$ & $2.50 \mathrm{E}-01$ & $1.44 \mathrm{E}-01$ \\
\hline & Minimum values & $3.58 \mathrm{E}-02$ & $2.82 \mathrm{E}-02$ & $2.74 \mathrm{E}-01$ & $1.66 \mathrm{E}-01$ & $7.63 \mathrm{E}-03$ & $5.32 \mathrm{E}-03$ & $9.88 \mathrm{E}-02$ & 3.57E-02 \\
\hline & Average values & $5.59 \mathrm{E}-02$ & $4.66 \mathrm{E}-02$ & 3.60E-01 & $2.41 \mathrm{E}-01$ & $1.17 \mathrm{E}-02$ & $1.12 \mathrm{E}-02$ & $1.66 \mathrm{E}-01$ & $8.53 \mathrm{E}-02$ \\
\hline & PTWI* & 30.00 & 107.14 & - & - & 30.00 & 107.14 & - & - \\
\hline
\end{tabular}

${ }^{*}$ Conversion of weekly tolerance to daily tolerance.

those in the intestinal stage were $2.17,1.99,5.43,2.35,3.94$, and $3.84 \mathrm{mg} / \mathrm{kg}$, respectively. The bioavailability amounts of heavy metals in the gastrointestinal stages were significantly different from each other. Except for $\mathrm{Cu}$, the amounts of the other heavy metals available in the gastric phase were higher than those in the intestinal stage. With a multiple regression model, the bioavailability of heavy metals can be predicted to a certain extent by using the total amount of heavy metals, the $\mathrm{pH}$, and the organic matter content. The bioavailability (BA) of heavy metals was as follows: $\mathrm{C}_{\mathrm{O}}(46.16 \%)>\mathrm{Cu} \quad(31.83 \%)>\mathrm{Ni} \quad(27.94 \%)>\mathrm{Pb}$ $(26.47 \%)>\operatorname{Zn}(14.38 \%)>\mathrm{Cr}(8.81 \%)$. In this study, although the bioavailability of $\mathrm{Pb}$ and $\mathrm{Cd}$ was lower than the corresponding limit values, the risks from heavy metals in soil ingested through the soil-oral cavity route will increase with the total amount of heavy metals in soil.

\section{Conclusion}

In the current study, the $\mathrm{pH}$ values in soils were between 7.93 and 8.14 and between 7.91 and 8.04 before rice sowing and at the harvesting period, respectively. The soil Eh ranged from -154.70 to $-144.00 \mathrm{mV}$ and -189.50 to $-180.60 \mathrm{mV}$ before the sowing of rice and at the harvesting period of rice, respectively. The organic matter content of soils was $23.64-26.24 \mathrm{~g} / \mathrm{kg}$ before the sowing period of rice and $47.13-54.15 \mathrm{~g} / \mathrm{kg}$ at the harvesting period. In both growth periods, the order of $E_{r}^{i}$ values was $E_{r}^{i}(\mathrm{Cd})>E_{r}^{i}(\mathrm{Hg})>E_{r}^{i}$ $(\mathrm{As})>E_{r}^{i}(\mathrm{~Pb})>E_{r}^{i}(\mathrm{Cu})>E_{r}^{i}(\mathrm{Cr})>E_{r}^{i}(\mathrm{Zn})$. However, the low RI values (90.96 and 29.97) for heavy metals demonstrated the low risk at both stages in the study areas were based on the potential ecological hazard index. Generally, in both growth periods, the proportions of the different heavy metal species were as follows: residual $>$ organic matterbound $>$ iron-manganese oxide-bound $>$ carbonate-bound $>$ exchangeable. The order of the values of accumulation and transfer factors was $\mathrm{Cd}(3.16)>\mathrm{Cu}(0.42)>\mathrm{Zn}(0.28)>\mathrm{Pb}$ $(0.25)>$ As $(0.07)>\mathrm{Cr}(0.04)>\mathrm{Cr}(0.03)$ and root $>$ stem $>$ leaves, respectively. In vitro tests showed that, in both adults and children, the amount of $\mathrm{Pb}$ and $\mathrm{Cd}$ in the daily intake through the soil-oral cavity route in the study area did not exceed the daily tolerance for $\mathrm{Pb}$ and $\mathrm{Cd}$ proposed by the WHO. In summary, although there is no obvious danger to local adults and children, it is necessary to be aware of the possibility of rice contamination from $\mathrm{Cd}$ in the soil.

\section{Data Availability}

The data used to support the findings of this study are included within the article.

\section{Conflicts of Interest}

The authors declare that they have no conflicts of interest.

\section{Authors' Contributions}

C. H. designed and wrote the research. W. X., C. C., and T. C. performed the experiments and data analysis.

\section{Acknowledgments}

This work was financially supported by the Environmental Engineering Subject with Open-End Fund in Key Laboratory in Jiangsu Province for Scientific Research (KF2015007), Surface Project of Scientific Research of Institutions of Higher Learning in Jiangsu Province (17KJB610002), and Environmental Engineering Subject with Open-End Fund in Key Laboratory in Jiangsu Province for Scientific Research (KF2015005).

\section{References}

[1] L. Zhang, B. Zhao, G. Xu, and Y. Guan, "Characterizing fluvial heavy metal pollutions under different rainfall conditions: Implication for aquatic environment protection," Science of the Total Environment, vol. 635, pp. 1495-1506, 2018.

[2] F. Chen, J. Lin, B. Qian et al., "Geochemical assessment and spatial analysis of heavy metals in the surface sediments in the eastern Beibu Gulf: A reflection on the industrial development of the south China coast," International Journal of Environmental Research and Public Health, vol. 15, no. 3, pp. 496-503, 2018.

[3] X. Pi, Y. Qiao, Y. Wei et al., "Concentrations of selected heavy metals in placental tissues and risk for neonatal orofacial clefts," Environmental Pollution, vol. 242, pp. 1652-1658, 2018.

[4] W. Sang, J. Xu, M. H. Bashir, and S. Ali, "Developmental responses of Cryptolaemus montrouzieri to heavy metals transferred across multi-trophic food chain," Chemosphere, vol. 205, pp. 690-697, 2018.

[5] X. Wu, J. Hu, J. Qi, Y. Hou, and X. Wei, “Graphene-supported ordered mesoporous composites used for environmental 
remediation: A review," Separation and Purification Technology, vol. 239, Article ID 116511, 2020.

[6] Z. Jia, J. Wang, B. Li et al., "An integrated methodology for improving heavy metal risk management in soil-rice system," Journal of Cleaner Production, vol. 273, no. 10, Article ID 122797, 2020.

[7] I. u. Khan, J. K. Rono, B. Q. Zhang et al., "Identification of novel rice (Oryza sativa) HPP and HIPP genes tolerant to heavy metal toxicity," Ecotoxicology and Environmental Safety, vol. 175, pp. 8-18, 2019.

[8] V. San, V. Spoann, and J. Schmidt, "Industrial pollution load assessment in Phnom Penh, Cambodia using an industrial pollution projection system," Science of the Total Environment, vol. 615, pp. 990-999, 2018.

[9] Y. Ren, Y. Chen, J. An et al., "Wheat expansin gene TaEXPA2 is involved in conferring plant tolerance to Cd toxicity," Plant Science, vol. 270, pp. 245-256, Article ID S0168945217307963, 2018.

[10] M. Wang, W. Chen, and C. Peng, "Risk assessment of Cd polluted paddy soils in the industrial and township areas in Hunan, Southern China," Chemosphere, vol. 144, pp. 346-351, 2016.

[11] X. Liu, G. Tian, D. Jiang, C. Zhang, and L. Kong, "Cadmium (Cd) distribution and contamination in Chinese paddy soils on national scale," Environmental Science and Pollution Research, vol. 23, no. 18, pp. 1-12, 2016.

[12] Z. Zhang, X. Wu, Q. Wu, X. Huang, J. Zhang, and H. Fang, "Speciation and accumulation pattern of heavy metals from soil to rice at different growth stages in farmland of southwestern China," Environmental Science and Pollution Research, vol. 27, no. 28, pp. 35675-35691, 2020.

[13] H. Wang, Q. Wu, W. Hu, B. Huang, L. Dong, and G. Liu, "Using multi-medium factors analysis to assess heavy metal health risks along the Yangtze River in Nanjing, Southeast China," Environmental Pollution, vol. 243, pp. 1047-1056, 2018.

[14] Y. Shen, Q. Chen, K. M. Zhang, and Y. M. Fang, "Risk assessment of heavy metal pollution by three plants at Zihu River in Nanjing, China," Applied Mechanics and Materials, vol. 535, pp. 403-408, 2014.

[15] Y. Zheng, D. Shen, S. Wu et al., "Uptake effects of toxic heavy metals from growth soils into jujube and persimmon of China," Environmental Science and Pollution Research, vol. 25, no. 31, pp. 31593-31602, 2018.

[16] L. Juen Lool, A. Zaharin Aris, F. Md. Yusoff, I. N. Mohd, and H. Hazzeman, "Application of enrichment factor, geoaccumulation index, and ecological risk index in assessing the elemental pollution status of surface sediments," Environmental Geochemistry \& Health, vol. 25, pp. 31593-31602, 2018.

[17] Y. Liu, Q. Wang, W. Zhuang et al., "Calculation of Thallium's toxicity coefficient in the evaluation of potential ecological risk index: A case study," Chemosphere, vol. 194, pp. 562-569, 2018.

[18] Y. Huang, Q. Chen, M. Deng et al., "Heavy metal pollution and health risk assessment of agricultural soils in a typical peri-urban area in southeast China," Journal of Environmental Management, vol. 207, pp. 159-168, 2018.

[19] L. Pan, J. Ma, Y. Hu et al., "Assessments of levels, potential ecological risk, and human health risk of heavy metals in the soils from a typical county in Shanxi Province, China," Environmental Science and Pollution Research, vol. 23, no. 19, pp. 19330-19340, 2016.
[20] Z. Fan, W. Wang, C. Tang et al., "Targeting remediation dredging by ecological risk assessment of heavy metals in lake sediment: A case study of shitang lake, China," Sustainability, vol. 11, no. 24, pp. 7251-7256, 2019.

[21] D. Huang, H. Gui, M. Lin, and W. Peng, "Chemical speciation distribution characteristics and ecological risk assessment of heavy metals in soil from Sunan mining area, Anhui Province, China," Human and Ecological Risk Assessment: An International Journal, vol. 24, no. 6, pp. 1694-1709, 2018.

[22] A. Yamada, Y. Ono, A. Kida, and K. Namiki, "Evaluation of bioavailability of heavy metals in soil by in vitro screening test," Chemistry Letters, vol. 32, no. 5, pp. 472-473, 2003.

[23] H. H. Ozaytekin and C. Uzun, "Comparison of weathering rates of the soils classified in alfisol and entisol order developed on limestone in the Taurus mountains at East Mediterranean Region," Carpathian journal of earth and environmental sciences, vol. 7, no. 1, pp. 109-120, 2012.

[24] S. Mehdi Ghoreishi, M. Behpour, E. Hajisadeghian, and M. Golestaneh, "Voltammetric determination of resorcinol on the surface of a glassy carbon electrode modified with multiwalled carbon nanotube," Arabian Journal of Chemistry, vol. 9, pp. s1563-s1568, 2016.

[25] W. Han, L. Luo, and S. Zhang, "Adsorption of tetrabromobisphenol A on soils: Contribution of soil components and influence of soil properties," Colloids and Surfaces A: Physicochemical and Engineering Aspects, vol. 428, no. 13, pp. 60-64, 2013.

[26] S. X. Liang, W. Xin, W. U. Hong, and H. Wu, "Determination of 9 heavy metal elements in sediment by ICP-MS using microwave digestion for sample preparation," Spectroscopy and Spectral Analysis, vol. 32, no. 3, pp. 809-812, 2012.

[27] J. Sastre, A. Sahuquillo, M. Vidal, and G. Rauret, "Determination of $\mathrm{Cd}, \mathrm{Cu}, \mathrm{Pb}$ and $\mathrm{Zn}$ in environmental samples: Microwave-assisted total digestion versus aqua regia and nitric acid extraction," Analytica Chimica Acta, vol. 462, no. 1, pp. 59-72, 2002.

[28] S. W. Song, G. C. Qi, H. Yu, Z. Y. Liu, and F. Z. Li, "Speciation analysis of heavy metals in sludge from a wastewater treatment plant," Applied Mechanics and Materials, vol. 448-453, pp. 376-379, 2014.

[29] M. Maanan, M. Saddik, M. Maanan, M. Chaibi, O. Assobhei, and B. Zourarah, "Environmental and ecological risk assessment of heavy metals in sediments of Nador lagoon, Morocco," Ecological Indicators, vol. 48, pp. 616-626, 2015.

[30] W. Yu and X. Zou, "The distributional characteristics of heavy metal in Jiangsu province shoal sea," Journal of Environmental and Public Health, vol. 2013, pp. 1-8, Article ID 142065, 2013.

[31] P. Saxena, V. Sangela, and Harish, "Toxicity evaluation of iron oxide nanoparticles and accumulation by microalgae Coelastrella terrestris," Environmental science and pollution research, vol. 27, no. 9, pp. 19650-19660, 2020.

[32] R. Singh, D. P. Singh, N. Kumar, S. K. Bhargava, and S. C. Barman, "Accumulation and translocation of heavy metals in soil and plants from fly ash contaminated area," Journal of Environmental Biology, vol. 31, no. 4, pp. 421-430, 2010.

[33] P. Yang, S. B. Liu, Y. H. Xie, Y. J. Zhou, D. Guan, and X. H. Ji, "Effect of thiol activated silicon on contents of cadmium in soil and rice under different $\mathrm{pH}$ conditions," Joumal of Henan Agricultural Sciences, vol. 47, pp. 46-51, 2018, in Chinese.

[34] H. C. Yang and Q. S. Yang, "Prevention and control technology of rice seedling Damping off disease," Rural Practical Technology, vol. 5, no. 4, p. 29, 2006, in Chinese. 
[35] L. Li, G. Z. Tian, W. D. Wang, and W. W. Chen, "Probe into efective phosphorus and total phosphorus of the paddy soil in the distribution region of nostoc sphaeroides," Journal of Hubei University for Nationalities (Natural Science Edition), vol. 31, pp. 81-84, 2013, in Chinese.

[36] Y. F. Xu, L. L. Xie, and M. K. Zang, "Characteristics and variations of soil fertility of paddy fields in river-network plains of Zhejiang," Chinese Agricultural Science Bulletin, vol. 7, pp. 29-34, 2017, in Chinese.

[37] L. X. Chen, Y. X. Song, X. Y. Yuan et al., "Distribution of Cd and impact factors on the migration in soil-rice system in typical area of Yangtze River delta region," Journal of Earth Sciences and Environment, vol. 33, pp. 288-293, 2011, in Chinese.

[38] K. Zhao, X. Liu, J. Xu, and H. M. Selim, "Heavy metal contaminations in a soil-rice system: Identification of spatial dependence in relation to soil properties of paddy fields," Journal of Hazardous Materials, vol. 181, no. 1-3, pp. 778-787, 2010.

[39] J. Shi, X. Yu, M. Zhang et al., "Potential risks of copper, zinc, and cadmium pollution due to pig manure application in a soil-rice system under intensive farming: a case study of Nanhu, China," Journal of Environmental Quality, vol. 40, no. 6, pp. 1695-1704, 2011.

[40] C. S. Seo, D. S. Huang, J. K. Lee et al., "Concentration of heavy metals, residual pesticides and sulfur dioxide of before/after a decoction," Korea Journal of Herbology, vol. 24, no. 1, pp. 111-119, 2008.

[41] J.-H. Park, J. J. Wang, R. Xiao et al., "Mercury adsorption in the Mississippi River deltaic plain freshwater marsh soil of Louisiana Gulf coastal wetlands," Chemosphere, vol. 195, pp. 455-462, 2018.

[42] F. Mohring, M. Rahbari, B. Zechmann et al., "Determination of glutathione redox potential and $\mathrm{pH}$ value in subcellular compartments of malaria parasites," Free Radical Biology and Medicine, vol. 104, pp. 104-117, 2017.

[43] K. Gondek, M. Mierzwa-Hersztek, and A. Unc, "Effect of lowtemperature biochar derived from pig manure and poultry litter on mobile and organic matter-bound forms of $\mathrm{Cu}, \mathrm{Cd}$, $\mathrm{Pb}$ and $\mathrm{Zn}$ in sandy soil," Soil Use and Management, vol. 32, no. 3, pp. 357-367, 2016.

[44] J. Bao, L. Wang, and M. Xiao, "Changes in speciation and leaching behaviors of heavy metals in dredged sediment solidified/stabilized with various materials," Environmental Science and Pollution Research, vol. 23, no. 9, pp. 1-8, 2016.

[45] H. H. Li, J. W. Liu, S. R. Li et al., "The present progness of research on heavy metal pollutionand plant enrichment in soil - plant system," Joumal of Henan Agricultural University, vol. 34, pp. 30-34, 2000, in Chinese.

[46] Z. Q. Zhen, S. P. Bian, J. M. Zhen, H. W. Feng, L. Z. Zhang, and S. L. Xing, "On agricultural environmental portection in line with farmland polluted by B and Cr in Xian," Journal of Northwest Agricultural University, vol. 3, no. 4, pp. 82-91, 1984, in Chinese.

[47] S. W. Yu and Y. B. Liu, "Current situation and prospects of researches on heavy metals pollution in soil - rice system," Acta Agriculturae Jiangxi, vol. 16, pp. 41-48, 2004, in Chinese.

[48] Y. Dai, C. F. Yang, and Y. M. Zhen, "A review on environmental behavior and toxicity assessment of chromium in soilplant system," Environmental Science, vol. 11, pp. 314-322, 2009, in Chinese.

[49] R. Chen, C. Zhang, Y. Zhao, Y. Huang, and Z. Liu, "Foliar application with nano-silicon reduced cadmium accumulation in grains by inhibiting cadmium translocation in rice plants," Environmental Science and Pollution Research, vol. 25, no. 3, pp. 2361-2368, 2018.

[50] Y. Du, X.-F. Hu, X.-H. Wu, Y. Shu, Y. Jiang, and X.-J. Yan, "Affects of mining activities on Cd pollution to the paddy soils and rice grain in Hunan province, Central South China," Environmental Monitoring and Assessment, vol. 185, no. 12, pp. 9843-9856, 2013.

[51] C. H. Zhang, H. U. Yan-Ling, J. U. Ting, and G. E. Ying, "Effect of solution $\mathrm{pH}$ on Cd absorption of rice seedlings," Guangxi Agricultural Sciences, vol. 38, no. 4, pp. 391-394, 2007.

[52] C. N. Reddy and W. H. Patrick, "Effect of redox potential and $\mathrm{pH}$ on the uptake of cadmium and lead by rice plants," Journal of Environmental Quality, vol. 6, no. 3, pp. 259-262, 1977.

[53] J. Y. Han, N. Zhang, X. L. Shu, and D. X. Wu, “Absorption of heavy metals in rice and the influence factors," China Rice, vol. 143 , no. 3 , pp. $48-52$, 2018, in Chinese.

[54] X. Hu, Y. Zhang, J. Luo, M. Xie, T. Wang, and H. Lian, "Accumulation and quantitative estimates of airborne lead for a wild plant (Aster subulatus)," Chemosphere, vol. 82, no. 10, pp. 1351-1357, 2011.

[55] L. D. Temmerman and H. Michel, "Vegetable crops for biomonitoring lead and cadmium deposition," Journal of Atmospheric Chemistry, vol. 49, no. 1-3, pp. 121-135, 2004.

[56] S. V. Sahi, N. L. Bryant, N. C. Sharma, and S. R. Singh, "Characterization of a lead hyperaccumulator shrub, Sesbania drummondii," Environmental Science \& Technology, vol. 36, no. 21, pp. 4676-4680, 2002.

[57] B. Pourrut, G. Perchet, J. Silvestre, M. Cecchi, M. Guiresse, and E. Pinelli, "Potential role of NADPH-oxidase in early steps of lead-induced oxidative burst in Vicia faba roots," Journal of Plant Physiology, vol. 165, no. 6, pp. 571-579, 2008.

[58] S. Samardakiewicz and A. Woźny, "The distribution of lead in duckweed (Lemna minor L.) root tip," Plant and Soil, vol. 226, no. 1, pp. 107-111, 2000.

[59] C. Khler, T. Merkle, and G. Neuhaus, "Characterisation of a novel gene family of putative cyclic nucleotide- and calmodulin-regulated ion channels in Arabidopsis thaliana," The Plant Journal, vol. 18, no. 1, pp. 97-104, 1999.

[60] S. Wojas, A. Ruszczyńska, E. Bulska, M. Wojciechowski, and D. M. Antosiewicz, " $\mathrm{Ca}^{2+}$-dependent plant response to $\mathrm{Pb}^{2+}$ is regulated by LCT1," Environmental Pollution, vol. 147, no. 3, pp. 584-592, 2007.

[61] M. Shahid, E. Pinelli, B. Pourrut, J. Silvestre, and C. Dumat, "Lead-induced genotoxicity to Vicia faba L. roots in relation with metal cell uptake and initial speciation," Ecotoxicology and Environmental Safety, vol. 74, no. 1, pp. 78-84, 2011.

[62] J. Brunet, G. Varrault, Y. Zuily-Fodil, and A. Repellin, "Accumulation of lead in the roots of grass pea (Lathyrus sativus L.) plants triggers systemic variation in gene expression in the shoots," Chemosphere, vol. 77, no. 8, pp. 1113-1120, 2009.

[63] H. B. Zhao, L. L. Li, T. N. Liang, Y. X. Zhang, F. G. Huang, and Q. G. Cao, "Advance in plant response to heavy metal Copper and Cadmium Stress," Journal of Anhui Agricultural Science, vol. 47, no. 21, pp. 14-16, 2019, in Chinese.

[64] I. Yruela, "Copper in plants: Acquisition, transport and interactions," Functional Plant Biology, vol. 36, no. 5, pp. 409-430, 2009.

[65] H. M. Gong and W. G. Li, "Research progress on the toxicity of zinc to plants and its mechanism," Journal of Anhui Agricultural Science, vol. 282, no. 29, pp. 14009-14015, 2009, in Chinese.

[66] X. L. Wang, T. Y. Liu, X. J. Xing, Z. Gao, Q. Li, and F. X. Yu, "Differences in the uptake and accumulation of $\mathrm{Cr}, \mathrm{As}, \mathrm{Zn}, \mathrm{Pb}$ 
and $\mathrm{Cu}$ from soil among six rice cultivars," Acta Agriculturae Universitatis Jiangxiensis, vol. 38, pp. 1009-1016, 2016, in Chinese.

[67] A. Lu, B. Li, J. Li, W. Chen, and L. Xu, "Heavy metals in paddy soil-rice systems of industrial and township areas from subtropical China: Levels, transfer and health risks," Journal of Geochemical Exploration, vol. 194, pp. 210-217, 2018.

[68] H. Chen, X. Yuan, T. Li, S. Hu, J. Ji, and C. Wang, "Characteristics of heavy metal transfer and their influencing factors in different soil-crop systems of the industrialization region, China," Ecotoxicology and Environmental Safety, vol. 126, pp. 193-201, 2016.

[69] X. F. Wang, C. B. Deng, G. P. Xu, and M. M. Wei, "Health risk assessment of heavy metals in soil by in vitro simulation method," Journal of Jiangsu Agricultural Science, vol. 45, no. 6, pp. 251-254, 2017, in Chinese.

[70] C. Chen, X. Y. Guo, M. Wang, Y. X. Jia, and S. B. Chen, "Human health risk assessment of $\mathrm{Cd}$ in vegetables and the remediation effect of Cd-polluted soil evaluated using an invitro simulation test," Journal of Agricultural Resources and Environment, vol. 37, pp. 144-150, 2020, in Chinese.

[71] D. Z. Lan, M. Lei, S. Zhou et al., "Health risk assessment of heavy metals in rice grains from a mining-impacted area in south Hunan by in vitro simulation method," Journal of AgroEnvironment Science, vol. 33, pp. 1897-1903, 2014, in Chinese.

[72] H. J. Wu, F. M. Fang, J. Y. Wu, Y. R. Yao, M. H. Wu, and Y. Kuang, "Accessibility and health risk of heavy metals at topsoil in primary schools in a coal Mining city," Chinese Journal of Science, vol. 48, pp. 1247-1255, 2017, in Chinese. 